\title{
The Franco-British Syndicalist Connection and the Great Labour Unrest, 1880s-1914
}

\section{Constance Bantman}

University of Surrey

This chapter explores the transfers between French and British trade unionism between 1880 and 1914, and the transnational elaboration of syndicalism in this period. The role of press exchanges and informal personal networks of influential militants is emphasized, as is the fact that influences between French and British militants travelled both ways - not simply from France to Great Britain, as is often assumed. Discourses on these cross-influences by contemporaries are also examined, in order to show that the transnational dimension of syndicalism was perceived and discussed at the time, often in terms of national character. The notable differences between these two brands of syndicalism are also examined, especially regarding the role of the state and the place of antimilitarism.

KEYWORDS: syndicalism, CGT, France, Great Britain, Great Labour Unrest, transfers

The Great Labour Unrest was one of these rare periods when the British gave the French a revolutionary lesson which the latter actually took on board and, less unusually, taught them a few things about trade unionism as well. It was the culmination of thirty years of cross-national exchanges and cross-fertilizations amidst the 'uneasy family' of European syndicalism. ${ }^{1}$ This contribution highlights these exchanges, based on the very productive Franco-British example, emphasizing in the first place their complexity. Influences travelled both ways and entailed adaptations and rewritings in order to bridge - not always successfully - significant ideological and organizational differences. These cultural transfers were rooted in the broader context of two very different trade-union movements in terms of ideology and structure, in a period nonetheless marked by similar political evolutions on both sides of the Channel, notably the rise of parliamentary socialism. This interplay of difference and similarity between both countries' respective labour traditions

1 Wayne Thorpe, 'The uneasy family. revolutionary syndicalism in Europe from the Charte d'Amiens to World War One', in David Berry and Constance Bantman, New Perspectives on Anarchism, Syndicalism and Labour: the Individual, the National and the Transnational (Newcastle, 2010), 16-42. 
explains the dynamics of such transfers. Secondly, the channels of this ideological dissemination are explored - such as mediators, personal networks and the press. These ideological exchanges were the result of an important internationalist endeavour and cannot be considered in isolation from the actors who set about importing and exporting syndicalist ideas, which played a significant role in the Great Labour Unrest.

Two caveats should be heeded, however. The first is that this Franco-British connection was very much derived from anarchist networks, although there is no underlying claim that British syndicalism was solely the offspring of anarchism, nor that French influences prevailed over those from New-Zealand, Australia or the United States. This paper simply focuses on one strand of the ideologically complex body of ideas and practices known as syndicalism, where anarchists appear to have played an important part at an early stage, chiefly through exilic contacts. Secondly, the focus is on the ideological rather than the grassroots level, bearing in mind how risky it is to try and identify influences, particularly because the connection between theories disseminated in rather small militant circles and masses of strikers is often difficult to evidence, especially when dealing with transnational connections. The complex issue of the grassroots diffusion of syndicalism has been flagged in the national context, notably by Peter Stearns's study on France's Confédération Générale du Travail (CGT), which painted the picture of very 'peaceful and moderate' French workers, precisely in those years when the CGT promoted very advanced watchwords. ${ }^{2}$ However, there is no doubt that transnational transfers were a significant element in the ideological and symbolical make up of the unrest - so much so that the transnational elaboration of syndicalism is commonly regarded as a model of globalization from below in this period. ${ }^{3}$

\section{Was British Syndicalism Derived from the French 'Model'?}

A short answer is, yes, partly. Influences of French syndicalism or proto-syndicalism in Britain can be traced back to the mid-1890s, when the anarchist periodicals The Torch and Freedom put to print the emergent activism of a handful of strongly internationalized militants in order to try and infuse trade unions with revolutionary ideas. These militants were Charles Mowbray,

2 Peter N. Stearns, Revolutionary Syndicalism and French Labor. A Cause without Rebels (New Jersey, 1971), 2.

3 Steven Hirsch and Lucien van der Walt (eds), Anarchism and Syndicalism in the Colonial and Postcolonial World, 1870-1940. The Praxis of National Liberation, Internationalism, and Social Revolution (Leiden, 2010). 
John Turner, Tom Keell, Alfred Marsh and Ted Leggatt, all of whom had had the opportunity to frequent French anarchists who later became prominent syndicalists during their exile in Britain in the early 1890s. ${ }^{4}$ Proto-syndicalist ideas had been developed in international circles where British, French and Italian activists played a prominent role. ${ }^{5}$ Propaganda in favour of trade union amalgamation, the general strike and sabotage, with references to the French CGT, really gained strength after 1907. It travelled through two main sources: first, The Voice of Labour, a weekly publication by anarchists with an interest in syndicalism, whose title was a direct translation of the CGT's own publication, La Voix du Peuple. From 1910, the main impact came from Tom Mann's propaganda and his Industrial Syndicalist Education League (ISEL), supported by small but efficient cross-Channel networks. After 1912 came the Glasgow-based paper The Anarchist. The translation of French syndicalist books was also a feature of the period, a case in point being Emile Pouget and Emile Pataud's Comment nous ferons la révolution which, in English, became Syndicalism and the Co-operative Commonwealth. How we shall bring about the Revolution. It appeared in 1913, in a translation by the anarchist Fred Charles and his wife, with a foreword by Tom Mann.

The Voice of Labour explicitly aimed to work towards the creation of a British syndicalist movement, and constantly referred to the French example: 'If France leads the way, other countries soon begin to echo her belligerent appreciation of the need for a new departure independent of political action' ${ }^{6}$ It called for organization, the political independence of trade unions, antimilitarism, direct action, and strikes. In the second issue, Aristide Pratelle wrote from France that his wish for the New Year was 'to see the workers across the Channel rapidly convinced that no one but themselves, and nothing but their own strength, will be able to gain them liberty and justice'. ${ }^{7}$ The contradiction between the CGT's 1906 declaration of political independence, the Amiens Charter, and the progress of parliamentary representation in Britain was often bemoaned: 'Just at the time when the French workers are leaving the barren path of political reform and taking that of direct action, the slowthinking English workers are drifting deeper into the mire of politics' ${ }^{8}$

4 John Quail, The Slow-Burning Fuse. The Lost History of the British Anarchists (London, 1978); Haia Shpayer, 'British Anarchism 1881-1914: Appearances and reality' (PhD dissertation, University College London, 1981).

5 Constance Bantman, 'Anarchismes et anarchistes en France et en Grande-Bretagne, 1880-1914: Échanges, Représentations, Transferts'(PhD dissertation, Paris 13 University, 2007), 359-68.

6 The Voice of Labour, 18 January 1907.

7 The Voice of Labour, 18 January 1907.

8 The Voice of Labour, 30 March 1907. 
However, despite numerous references to France, and the fact that the latter was depicted as a key example, the main impetus for this syndicalist drive was the perceived failure of the Labour Party's first year in power - 'the miserable palliatives of a dying system'. ${ }^{9}$ The immediate context for both the creation of The Voice of Labour and the broader syndicalist push was the widespread disappointment brought about after the first year in power of the Progressive Alliance between the Liberals and the new Labour Party; key themes were the slow pace of reform (hence the need for the workers to take matters in their own hands) and the idea that careerism and self-interest were rampant among the Labour Party's members of Parliament. Within years, although the larger newspapers consistently presented syndicalism as a foreign importation, interpreting it as the product of British developments became fairly common amidst more discerning audiences, such as the Trades Union Congress (TUC): 'Whatever [Syndicalism] may be in France or elsewhere, it is here a protest against the inaction of the Labour Party'. ${ }^{10}$ The Voice of Labour's editors placed syndicalism in a genealogy of British labour protest which included Robert Owen's Grand National Consolidated Trades Union and the early days of New Unionism in the late 1880s: 'Above all there must be a revival of that militant policy of direct action which in the early nineties of last century did so much to inspire the poorest workers in the country with the serious determination of fighting the exploiters at the point where they secure their plunder. ${ }^{11}$

This insistence on a national legacy points to the limits of ideological import' theories: there was indeed an attempt to nationalize, or localize syndicalism, but it was not simply a foreign graft, as it was also understood as a revival of Britain's own revolutionary heritage, which was an important reference point. However, even if national politics are regarded as the key determinant in the rise of syndicalism, there is also a transnational dimension since the institutionalization of parliamentary socialism in different Western countries triggered a 'rejection of the dominant labour strategy' which is widely acknowledged to have favoured the expansion of syndicalism. ${ }^{12}$ In the case of Britain, this meant denouncing the collusion of mainstream unions with the Labour Party; in France, where the main trade union organization, the CGT, was officially syndicalist, protests focused on the limitations of

9 The Voice of Labour, 30 March 1907.

10 G.H. Stuart (Postmen's Federation), Report of the 1912 Trades Union Congress, 274.

11 The Voice of Labour, 3 February 1907.

12 Wayne Thorpe and Marcel van der Linden, 'The rise and fall of revolutionary syndicalism', in Thorpe and van der Linden (eds), Revolutionary Syndicalism. An International Perspective (Aldershot: Scholar Press, 1990), 12. 
parliamentary socialism; tellingly, the Amiens Charter was adopted partly to restate the independence of the trade union movement following the consolidation of various parliamentary socialist groupings into a unified party, the SFIO (Section Française de l'Internationale Ouvrière), in 1905. ${ }^{13}$ It is therefore hardly surprising that contemporaries perceived the unity of syndicalism, despite their national differences. The Bulletin international $d u$ mouvement syndicaliste hinted at such similarities with its list of labour leaders who had been lost to the cause after entering Parliament: 'Millerand, Viviani, Briand, John Burns. Who's next?'14

The Voice of Labour lasted for seven months, with a limited readership but a very active pool of militants; it also spawned new initiatives, such as Guy Aldred's dissident Industrial Union of Direct Actionists. And thus French ideas percolated into British militant circles. 1910 was a turning point. Tom Mann came back from Australia in May, having left Britain in 1901 as a supporter of parliamentary action, and famously returning as a critic of arbitration and a champion of direct action over parliamentary ways. By then, he had set up the ISEL with Guy Bowman. Both men soon left for France to meet with French CGT members, through the intermission of the Confederation's treasurer Charles Marck. There, Mann gave several speeches and met the editorial team of the two leading French-language syndicalist publications, both of which had a very international outlook, Christian Cornelissen's Bulletin international du mouvement syndicaliste and La Vie ouvrière, led by a core of working-class and non-working-class writers, including Pierre Monatte and the United States-born Alfred Rosmer. ${ }^{15}$ Upon their return, Mann and Bowman launched The Industrial Syndicalist in order to publicize their critique of parliamentarianism and contemporary trade unionism, the French-inspired strategy of boring from within (as opposed to the American strategy of setting up an alternative, strictly syndicalist organization), and, unsurprisingly, the French reference featured prominently:

Now, without urging a close imitation of the French or any other method, I strongly believe that, on the average, the French policy is one that will suit us best; for whilst the temperament of the French is undoubtedly different

13 Jacques Julliard, Clemenceau briseur de grèves. L'affaire de Draveil - Villeneuve-Saint-Georges (Paris, 1965); Jacques Julliard, 'La Charte d'Amiens, cent ans après. Texte, contexte, interprétations', Mil Neuf Cent. Revue d'histoire intellectuelle 24 (2006), 5-40; Collectif, Le Congrès de la Charte d'Amiens (Paris: Éditions de l'Institut CGT d'histoire sociale, Collection 'Les congrès de la CGT', 1983).

14 'Millerand, Viviani, Briand, John Burns. Qui suivra ?', in Bulletin international du mouvement syndicaliste, 57 (18 May 1908).

15 La Vie ouvrière, introduction by Colette Chambelland. 
from that of the British, their interests are exactly as ours, and their enemy is also as ours - the capitalist system. ${ }^{16}$

The French also garnered praise as a model of class solidarity:

It is, indeed, a magnificent lesson in class solidarity that the French comrades are teaching ... The world over, the workers will profit by this splendid example. ${ }^{17}$

The chief difference between French and British workmen is this: the French have instinctively and rationally a keener appreciation of class solidarity. ${ }^{18}$

There was probably an implicit reference to the French anarchist journalist Fernand Pelloutier's Histoire des Bourses du travail in the recurring theme of the appropriation of the means of production by the working class as the first step towards the creation of a socialist republic, which was an important syndicalist idea. Bowman was especially influenced by Pelloutier's ideas, and took up his ideal of the Bourses du travail (labour councils) as the cells and the prefiguration of post-revolutionary society: ${ }^{19}$

The economic emancipation of the working class can only be secured by the working class asserting its power in workshops, factories, mills and mines, on ships and boats and engines and wherever work is performed, ever extending their control over the means of production until, by the power of the internationally organised Proletariat, capitalist production shall entirely cease, and the Industrial Socialist republic will be ushered in, and thus the social revolution realised..$^{20}$

Conferences spread the same idea: 'In all these provincial meetings, I explained the CGT's fighting methods, and these methods were received warmly', Mann announced. ${ }^{21}$ The impact is likely to have been significant, as the rallies addressed by Mann occasionally counted representatives of as many as 60,000 individuals.

Mann was also helped in his French-inspired propaganda by Madame Antoinette Sorgue, a very active lady of upper-class extraction who became a prominent syndicalist supporter until the First World War. Her presence in Britain was noted in 1910, when she attended a transport workers' meeting, and from then on she appeared as a champion of Franco-British working-class

16 The Voice of Labour, 30 March 1907.

17 The Industrial Syndicalist, October 1910.

18 The Industrial Syndicalist, October 1910.

19 Bob Holton, 'Syndicalist theories of the state', Sociological Review, 28. (1980), 5-21, 11.

20 The Industrial Syndicalist, March 1911.

21 Bulletin international du mouvement syndicaliste, 3 July 1910. 
solidarity. The Bulletin international du mouvement syndicaliste reported closely on her militant activities: 'Citizen Sorgue (from France) spoke in favour of a concerted action from English and French transport workers against the Employers' Federation. Sorgue called on the English workers' solidarity in the event of a general railway strike in France'. ${ }^{22}$ In 1911, Sorgue could be found in Hull and many other cities, tirelessly advocating Franco-British and international direct action and solidarity, just as the sailors' strike was starting. ${ }^{23}$

These efforts towards concrete organization, especially with a view to the international general strike, generally petered out. One high point was the 1911 sailors' strike. Mann was especially active in trying to organize the strike, which had important international ramifications, although, notably, the French did not take part. On this occasion, Mme Sorgue wrote in the Bulletin international: 'I return from England with conviction that the CGT's revolutionary method will increasingly be applied among pour friends across the Channel. Decided men like Ben Tillett, Havelock Wilson and Cathery are ready to ally with militants from Paris and form an 'entente cordiale' which will be far more fruitful and significant than that which we so frequently hear of.$^{24}$ This, however, was to remain a dead letter.

\section{Ideological Differences and Echoes: the Role of the State and Antimilitarism}

Nonetheless, there was a profound divergence with French syndicalism, as Mann did not reject political action altogether: 'Let the politicians do as much as they can, and the chances are that, once there is an economic fighting force in the country, ready to back them up by political action, they will actually be able to do what now would be hopeless for them to do'. ${ }^{25}$ A debate which took place at the TUC in 1913 emphasized that the opposition to parliamentary politics was more contextual and pragmatic than ideological. Ralph Darlington has also noted that 'some individual figures within the syndicalist movement did not entirely discount the potential value of 'political action' ... although the leading figures within the syndicalist

22 Bulletin international du mouvement syndicaliste, 3 July 1910.

23 Yann Béliard, 'Outlandish 'isms' in the city: how Madame Sorgue contaminated Hull with the virus of direct action', Recherches Anglaises et Nord-Américaines, 36 (2003), 113-25.

24 Bulletin international du Mouvement Syndicaliste, 5 March 1911.

25 The Industrial Syndicalist, 10 July 1910. 
movement internationally saw the unions as the main area of struggle'. ${ }^{26}$ This was a very significant difference, which contemporaries tended to discount in racialist terms, by claiming that 'the British' were more pragmatic than the French. Instead, it is best interpreted as a legacy of the influence of anarchism over French syndicalism, and the consequence of the absence of a tradition of conciliation between workers and the state, in a period when the state played a decisive role in the repression of labour conflicts. French syndicalism was also rooted in a number of national traditions which explained its specific features, including anti-statism: the French revolutionary tradition, craft socialism, with its emphasis on working-class autonomy, the legacy of the First International. ${ }^{27}$ Across the Channel, the influence of the American De Leonites's Industrial Unionism provides another explanation for these divergent perceptions of the state. ${ }^{28}$ This lesser hostility to the state appears in the discourse of Britain's leading syndicalists, and in particular in one of the period's key manifestoes, The Miners' Next Step, which provides evidence that 'syndicalism shaded into a militant parliamentarianism which stressed the necessity of coordinating industrial and political tactics' ${ }^{29}$

This difference also testifies to the divergent aims of the two movements. In the British case, the thinly-veiled statism of part of the syndicalist movement confirms that the strikes of 1911-1914 must also be interpreted in a medium-term perspective, as the completion of the process of massification, amalgamation and, to a limited extent, radicalization of the trade unions started in the $1870 \mathrm{~s} .{ }^{30}$ One of the recurring features of the period was an increased militancy, with a view to obtaining greater state involvement in the regulation of labour conflicts. The pre-war strikes may well have been described by their French contemporaries as the symbol of the failure of parliamentary socialism and state arbitration; however, these events have retrospectively been described as a call for greater state involvement, heralding an interventionist age after decades of liberalism. ${ }^{31}$

26 Ralph Darlington, Syndicalism and the Transition to Communism. An International Comparative Analysis (Farnham, 2009), 24.

27 Bernard Moss, The Origins of the French Labor Movement. The Socialism of Skilled Workers, 1830-1914 (Berkeley and Los Angeles, 1976).

28 Holton, 'Syndicalist Theories of the State', 8-9.

29 Unofficial Reform Committee, The Miners' Next Step, Being a Suggested Scheme for the Reorganisation of the Federation, Merfyn Jones (dir.), London, 1973 (1912); John Belchem, Popular Radicalism in Nineteenth-Century Britain (Basingstoke, 1995), 176.

30 Wolfgang Mommsen and Hans-Gerhardt Husung (eds), The Development of Trade Unionism in Great-Britain and Germany, 1880-1914 (London, 1985).

31 George Dangerfield, The Strange Death of Liberal England (London, 1936).; G.D.H. Cole and Raymond Postgate, The Common People 1746-1938 (London, 1961 (1938)), 450-80; Keith Aikin, The Last Years of Liberal England, 1900-1914 (London, Glasgow, 1972). 
Antimilitarism, which featured prominently in French syndicalism another anarchist legacy - also travelled across the Channel. Antimilitarist agitation culminated in Britain in January 1912, with the publication of the infamous Don't shoot manifesto in the ISEL's monthly The Syndicalist. The pamphlet rehearsed a familiar theme: soldiers, who belong to the same social class as the workers, should not betray class solidarity, and refuse to shoot them when called upon to repress strikes. In France, where there was a longstanding hostility between the working classes and police and army forces, there existed a long tradition of antimilitarism in labour and protest movements, compounded by the general hatred of compulsory military service. ${ }^{32}$ But such appeals, which would have been unlikely to meet with any echo in Britain before the period of the Great Labour Unrest, were given added resonance in those years, as the police and army intervened ever more frequently to repress labour conflicts. Consequently, the antimilitarist theme was imported into Britain. Key French antimilitarist texts were translated and disseminated. Guy Bowman, who spoke French, translated into English Gustave Hervé's Ma Patrie, the seminal text of French antimilitarism for syndicalists. Hervé went on a conference tour of Britain in October 1912, giving a speech entitled 'War against War' in Shoreditch and then Manchester. ${ }^{33}$ The conference's title came from a famous CGT pamphlet, aimed at rallying foreign movements to the antimilitarist cause. Several CGT dignitaries attended Hervé's conference, including Léon Jouhaux, the Confederation's general secretary; the following year, Jouhaux addressed the TUC along similar lines, with similar exhortations to oppose the war with the general strike.

When the strikes of the Great Labour Unrest started, action took over propaganda and discourses; the specificities of the British industrial and trade union context, as well as the weaknesses of the CGT appeared, so that the French reference was dropped. The Syndicalist still bore the traces of Mann's interest in the French movement, with references to French-style antimilitarism, but a much more cautious stance towards French syndicalism was manifest: '[The general strike] has not had a very brilliant success in France but it has undeniably caught on here'. ${ }^{34}$ Whilst France was still described as 'being pervaded with the ideology of sabotage, it was mentioned rather rarely and, more importantly, was no longer presented as a model.

It therefore appears that, during the years 1906-1911, French syndicalism

32 Michel Cordillot, 'L'Affiche rouge de février 1906', in Cordillot (ed.), "Plutôt l'insurrection que la guerre! " L'antimilitarisme dans l'Yonne avant 1914 (Auxerre : Adiamos 89/SSHNY, 2005), 21-51.

33 The Syndicalist, October 1912.

34 The Syndicalist, January 1912. 
played an important role in the self-definition of British syndicalism. Indeed, this French connection of British syndicalism was so well-known that it became something of a cliché and a theme of reflection and speculation in its own right. The French origins of the word 'syndicalism' were repeatedly flagged. On 16 April 1912, The Times published a long article which started with a literature review in order to assess whether it was surprising, or even possible, for syndicalism to take root in a non-Latin culture: 'Syndicalism is something specially Franco-Italian, or perhaps more exactly French, and ... it could not have developed in any other land'. ${ }^{35}$ Of course, France's syndicalisme révolutionnaire was not the only ideological influence at play in the unrest, and its adaptation was always bound by specifically British circumstances and constraints, starting with the strength and influence of reformist trade unionism. The British context was almost diametrically opposed to the French situation in this respect, as the CGT was characterized by its numerical weakness and its revolutionary stance (in its rhetoric rather than its practice). This contrast is one of the limitations which the anarchist Max Nettlau had in mind when, in 1910, he wrote to Tom Keell: 'I think it is not only useless but illogical to expect to introduce French and American syndicalist methods in England: just as no one would hear of German methods. Just as impossible as to introduce French habits and methods and French temper in public life. In France the labour movement was neglected over politics, and the syndicalists had and still have to make the greatest noise possible, to bluff in every way, to make themselves heard ... The English unions, old and firmly established, have no need to be noisy ... All the workers [illegible] are organised in England and have far more real power than the French syndicalists have', ${ }^{36}$

This is a very apt remark, which shows again how the anarchists and syndicalists of the period were used to thinking in terms of what is now known as cultural or militant transfers. However, two layers of complexity must be added to the account of Franco-British syndicalist cross-influences.

\section{Lesser-Known Transfers: British Influences on French Syndicalism}

First, the French syndicalist model itself was partly derived from British influences, notably through the experience of exile. The strikes of the late 1880s, which had marked the beginning of New Unionism in Britain, had

35 The Times, 16 April 1912, 'Syndicalism. The Movement in England'.

36 Freedom archive, IISH, Amsterdam, Correspondence, letter from Max Nettlau to Thomas Keell dated 22 March 1910. 
stimulated the anarchist reflection on the uses of trade unions and the general strike in the context of a revolutionary strategy. In the early 1890s, exiled anarchists who lived in London came to look at and write about British trade unions as examples of militancy on the economic terrain, free of state interference. These ideas were mostly to be found in the writings of the Italian Errico Malatesta, the French Emile Pouget (one of the founding fathers of syndicalism) and the Russian Peter Kropotkin, all of whom pointed to trade unionism as a model of organization, and based this advocacy on different types of arguments. In the early- to mid-1890s, a number of French or Francophone militants who later became prominent or influential within the CGT developed proto-syndicalist ideas in reference to the British example, with increased frequency, until about 1897. The 1896 London congress of the Second International, which resulted in the expulsion of anarchists from the organization, provided an opportunity for the French attendants of anarchist or proto-syndicalist tendency to meet and form links with some British trade unionists and socialists who supported them openly following their expulsion. James Keir Hardie was one of those who attended fringe meetings organized in protest to the treatment of anarchists, but the most influential was of course Tom Mann, who was still a parliamentarian member of the Social Democratic Federation (SDF) at the time, but nonetheless stood for a pluralist International. Through the personal experience of exile and direct observation of British unions, through these informal personal connections and the anarchist and proto-syndicalist press's close attention to international militant practices, French ideas on the general strike, the use and organization of trade unions, sabotage were all developed with reference to British unionism. Emile Pouget, who had been a keen observer of British trade unions, explicitly encouraged French workers to emulate their British counterparts' use of boycott. ${ }^{37}$ For all the differences between French and British trade unionism at the time, there were also a number of similarities which created favourable conditions for ideological transfers - and also blurred the difference between 'revolutionary' and 'reformist' approaches: 'Many traits can create similarities between directaction syndicalism and British syndicalism ... Just as in the United Kingdom, craft-based unions were fiercely protective of their autonomy and often quite defiant towards the state and political institutions, favouring direct relations with employers. However, there were also striking differences since, against the trade unionists' pragmatism and book-keeping, the French trade unionists tended to prefer revolutionary discourses and gestures and, rather

37 Constance Bantman, 'The Militant Go-Between. Emile Pouget's Transnational Propaganda, 1880-1914’, Labour History Review 74 (2009), 274-87. 
than negotiations ... they tended to prefer action, or even strikes, ${ }^{38}$ Rather than the traditional image of a unilateral influence from the CGT over the British working class, via syndicalist propaganda, it is therefore more relevant to conceive of these cross-influences as a complex reflection on syndicalism, which did not travel from one influencing movement (the French one) to a passive recipient, but rather consisted in a to-and-fro exchange of ideas.

This is all the more apt in view of the second wave of British influence over French trade unionism, as influences travelled back across the Channel from 1910 onwards. Around that time, the CGT was faced with a manifold crisis, caused by the profound ideological rift in its midst between reformists and revolutionaries, chronically low numbers made worse by the failure to mobilize workers despite its very radical stance, as evidenced by the flop of the much-anticipated general strike of May Day 1906. The first decade of the century also saw unprecedented levels of governmental repression under the aegis of Home Secretary Georges Clemenceau, marked by the arrest of several key leaders in the organization. At the international level, the CGT found itself isolated as the only revolutionary federation in the International Secretariat of Trade Union Centres. ${ }^{39}$ In this context, developments occurring across the Channel provided hope for the cause, and also pointed to possible solutions to the French crisis. The influence now exerted by the British example manifested itself in several different ways. ${ }^{40}$ First, the two key French syndicalist publications La Bataille syndicaliste and La Vie ouvrière closely followed Tom Mann's activities and chronicled his ideological evolution. A key theme whenever the British unrest was mentioned was the difficulty of knowing whether reformist Britain might actually be turned into a revolutionary nation: 'The mining strikes in Wales have just led to violent resistance against the introduction of blacklegs in factories and even to sabotage orders, which we thought only happened in France and other countries with a strong and lively syndicalist movement'. ${ }^{41}$

By 1911, the idea of Britain as a model was beginning to be openly discussed. From then on, there were weekly articles in the French syndicalist press about events across the Channel; however, this enthusiasm was mitigated

38 Jean-Louis Robert, Friedhelm Boll, Antoine Prost (eds), L'invention des syndicalismes. Le syndicalisme en Europe occidentale à la fin du XIXe siècle (Paris, 1997), 14.

39 Susan Milner, The Dilemmas of Internationalism. French Syndicalism and the International Labour Movement, 1900-1914 (Oxford, 1990).

40 The modalities of this influence have been studied in detail in Jean-Louis Auduc's MA dissertation. 'Le Mouvement syndical anglais à travers la presse syndicaliste française, 1911-1914' (Université Paris I, 1973). A few key points are summarised here.

41 Bulletin international du mouvement syndicaliste, 13 November 1910. 
by the difficulties which the British movement encountered: strategic divisions as to the status of syndicalism with the debate over 'boring from within', a lack of cross-industrial solidarity, as well as the die-hard parliamentarianism of several federations. However, in the face of the strikes unfolding across the Channel, some French observers declared: 'It is the revolutionary past and truly democratic social life of the English people, this national character which so profoundly distinguishes this people ... which explains this phenomenon. All in all, this is the realisation of all our revolutionary doctrines'. ${ }^{42}$ The irony of this period is epitomized in these words: indeed, when it came to syndicalism, the French may have been strong on the theoretical side, but failed the crucial action test. There may well have been a causal link between both aspects: as Barbara Mitchell has suggested, the ideological radicalism of the CGT was to some extent a compensation for its actual weakness in terms of numbers and organization. ${ }^{43}$

\section{Conclusion}

The Great Labour Unrest was one of the climaxes of the first globalization in the labour movement, as symbolized by the trajectory of the antimilitarist component of syndicalism, which went from antipatriotism and internationalism to militarism and interventionism. Of course, one may say that these were just a handful of militants looking at developments beyond their own borders, reporting back and inciting everyone to carry on - but this in itself was a new fact of this period, when a number of key mediators played a leading role in the internationalization of the labour movement.

What does this wave of cross-influences suggest? With respect to the field of transnational labour history, recent hypotheses are confirmed: the role of informal networks, individual militants, the press, the fact that there were no unilateral influences from a hegemonic syndicalist movement (France), but rather a constant interplay where ideas travelled back and forth and were adapted and reinterpreted in different national contexts. Regarding political and social history, this case study highlights the place of syndicalism and the pre-WW1 strike wave as a stage in the history of modern democracies and parliamentary socialism. In both countries, the emergence of syndicalism was linked to increased workers' mobility in an increasingly international

42 Bulletin international du mouvement syndicaliste, 13 August 1911.

43 Barbara Mitchell, The Practical Revolutionaries. A New Interpretation of the French Anarchosyndicalists (New York, 1987). 
labour market, the bureaucratization of trade unions, worker integration and the disappointment with parliamentary socialism. However, significant differences must also be highlighted. These pertain chiefly to the doctrinal contents being disseminated (notably regarding the position of trade unions with respect to the state) and to the different possibilities created by the existing trade union movement.

\section{Note on Contributor}

Constance Bantman is a lecturer in French at the University of Surrey, UK. Her research focuses on the links between the French and British anarchist and syndicalist movements between 1880 and 1914, with broader interests in Anglo-French political and cultural exchanges in the long nineteenth century, the history of the pre-WW1 international anarchist movement, as well as the theory and methodology of transnational history. Her publications include New Perspectives on Anarchism, Labour and Syndicalism: The Individual, the National and the Transnational (with Dave Berry, Cambridge Scholars Publishing, 2010) and The French Anarchists in London. Exile and Transnationalism in the First Globalization (Liverpool University Press, 2013). Correspondence to: c.bantman@surrey.ac.uk 